\title{
RETRACTED: Penerapan Metode Simple Additive Weighting (SAW) dan Tabel Keputusan pada Sistem Pendukung Keputusan Menentukan Tingkat Punishment Siswa Bermasalah
}

\author{
Riyadi Purwanto ${ }^{1 *}$, Dwi Novia Prasetyanti ${ }^{2}$, Ratih Hafsarah Maharrani ${ }^{3}$, Lutfi Syafirullah ${ }^{4}$ \\ 1,2,3,4Program Studi Teknik Informatika, Politeknik Negeri Cilacap \\ ${ }_{1,2,3,4} \mathrm{Jln}$. Dr. Soetomo No.1 Karangcengis Sidakaya, Kabupaten Cilacap, 53212, Indonesia \\ E-mail: adidokbayu85@gmail.com¹, dnpr4s3ty4nt1@gmail.com², ratih.hafsarah@pnc.ac.id ${ }^{3}$, \\ syafirullah.lutfi@gmail.com ${ }^{4}$
}

\section{Info Naskah:}

\section{Article history}

Retraction notice to "Penerapan Metode Simple Additive Weighting (SAW) dan Tabel Keputusan pada Sistem Pendukung Keputusan Menentukan Tingkat Punishment Siswa Bermasalah" Vol.12 No.2 July 2021, pp.115-121

DOI: 10.35970/infotekmesin.v12i2.780

Retracted on January 27, 2023

\section{Abstrak}

Following a rigorous, carefully concerns and considered review of the article published in Infotekmesin to article entitled "Penerapan Metode Simple Additive Weighting (SAW) dan Tabel Keputusan pada Sistem Pendukung Keputusan Menentukan Tingkat Punishment Siswa Bermasalah " Vol 12, No 2, pp.115-121, July 2021, DOI: https://doi.org/10.35970/infotekmesin.v12i2.780

This paper has been retracted at the request of the author of this article because by mistake the same article has been published in another journal publisher.

The article contained redundant material, the paper published in Proceedings of the 4th International Conference on Applied Science and Technology on Engineering Science - iCAST-ES, ISBN 978-989-758-615-6; ISSN 2975-8246, pages 1194-1202. DOI: 10.5220/0010962300003260,

The document and its content has been removed from Infotekmesin, and reasonable effort should be made to remove all references to this article. 